\title{
LUT
}

University

\section{The role of motivations and self-concepts in university graduate} entrepreneurs' creativity and resilience

Nisula Anna-Maija, Olander Heidi

This is a Final draft version of a publication

published by Taylor \& Francis

in Journal of Small Business Management

DOI: $10.1080 / 00472778.2020 .1760030$

Copyright of the original publication: (c) 2020 Informa UK Limited

Please cite the publication as follows:

Anna-Maija Nisula \& Heidi Olander (2020) The role of motivations and self-concepts in university graduate entrepreneurs' creativity and resilience, Journal of Small Business Management, DOI: 10.1080/00472778.2020.1760030

This is an Accepted Manuscript of an article published by Taylor \& Francis in Journal of Small Business Management on 21 Aug 2020, available online: http://www.tandfonline. com/10.1080/00472778.2020.1760030.

This is a parallel published version of an original publication. This version can differ from the original published article. 


\title{
The role of motivations and self-concepts in university graduate entrepreneurs' creativity and resilience
}

\author{
Anna-Maija Nisula *) \\ Associate professor \\ LUT University \\ School of Business and Management \\ Mukkulankatu 19, FI-15210 Lahti, FINLAND \\ Email: anna-maija.nisula@lut.fi
}

\author{
Heidi Olander \\ Associate professor \\ LUT University \\ School of Business and Management \\ Mukkulankatu 19, FI-15210 Lahti, FINLAND \\ Email: heidi.olander@1ut.fi \\ *) Corresponding author
}

This is a final draft version of an article published by Taylor \& Francis online and is in press in JSBM. Reference: Nisula, A-M, and Olander, H. (in press). The role of motivations and self-concepts in university graduate entrepreneurs' creativity and resilience, Journal of Small Business Management, DOI: $\underline{10.1080 / 00472778.2020 .1760030}$

Copyright (C) 2020 Informa UK Limited

\begin{abstract}
Creativity and resilience are critical capacities for entrepreneurs in today's economy. We investigated university graduate entrepreneurs' individual determinants such as entrepreneurial motivations and positive self-concepts in relation to entrepreneurs' creativity and resilience. Specifically, we tested the proposed research model using a survey data collected from university graduate entrepreneurs and pre-entrepreneurs in the field of technology. Our results show that the antecedents of creativity and resilience were contingent on the type of entrepreneurs. We discuss theoretical and practical implications of our study.
\end{abstract}

Keywords Entrepreneur, pre-entrepreneur university graduate creativity, resilience, motivation, self-efficacy, internal locus of control 


\section{Introduction}

While research on academic entrepreneurs covers graduate entrepreneurship within academia (for example, Miller et al. 2018; Mosey and Wright 2007;), surprisingly little research has been conducted on university graduate entrepreneurs outside academia. However, university graduates work as entrepreneurs (Åsterbro, Bazzazian, and Braguinsky 2012; Hsu, Roberts, and Eesley 2007), entrepreneurial freelancers in contractual project-based work (Born and Witteloostuijn 2013; Silverstone et al. 2015), and intrapreneurs (Guerrero and Urbano 2013) outside academia, or they divide their working time between academia and entrepreneurship. In fact, new work, the rapid changes in working life, and economic turbulence in various societies are widely promoting opportunities for university graduates to consider entrepreneurship outside academia, at least in part. This is why universities, labour market organisations, and trade unions for university graduates are more and more likely to provide entrepreneurship education and training (Clarysse et al. 2011; Jansen et al. 2015) and support (Grimaldi and Grandi 2005) for students' and graduates' entrepreneurship. However, except for some attractive entrepreneurial environments in universities, such as the Massachusetts Institute of Technology (Hsu et al. 2007) and Stanford Graduate School of Business (Lazear 2005), the entry threshold for entrepreneurship remains high for university graduates (Greene and Saridakis 2007; Pickernell et al. 2011). For example, among Finnish university graduates in the field of technology and architecture, only 6 percent (of 70,000 Academic Engineers and Architects in Finland [TEK] members) are entrepreneurs (TEK Labour Market Survey 2018). One explanation for this is that the majority of university graduates execute entrepreneurship as intrapreneurs. Another explanation and a far less studied one is the individual-level barriers that inhibit them from becoming entrepreneurs, such as the lack of skills and knowledge to capture opportunities (Miller et al. 2018) and the inability to compromise between tensions, such as generating novel opportunities and implementing them or balancing between entrepreneurial autonomy and the responsibility for career success.

As creating and running a venture is not an obvious career choice among university graduates, shedding light on the personal capacities that drive the decision for entrepreneurship and that address individual barriers to entrepreneurship is important. While acknowledging the importance of contextual factors, such as government support (Bennett and Robson 2003), informal support (Greene and Saridakis 2007), university support (Åsterbro et al. 2012), and business advice (Pittaway and Cope 2007), in university graduate entrepreneurship, we limit our research to individual factors and propose that all entrepreneurs face challenges despite their context; therefore, they need capacities such as 
individual creativity and resilience - similar to imagination and courage (Hitt, Ireland, Camp, and Sexton 2002; Miller and Le Breton-Miller 2017) — to start and run a venture and to orchestrate it as an entrepreneur in the contemporary economy. Particularly, we identified two central tensions in which creativity and resilience are critical.

First, an entrepreneur faces a tension that demands individual creativity and imagination to create business concepts, products, and services and to capture opportunities (Zhou 2008; Amabile 1997), as well as the resilience to address the emerging adversities and barriers when starting and running a venture. Surprisingly, we know little about the factors beyond individual entrepreneurs' creativity and resilience, although extant research associates creativity with knowledge work (Dul et al. 2011), entrepreneurial processes (Chen and Yang 2009; Zhou 2008), entrepreneurial intentions (Biraglia and Kadile 2017), and entrepreneurship (Zhou 2008). Similarly, resilience - an individual's ability to overcome and cope with adversity (Sinclair and Wallston 2004) — is associated with entrepreneurial intentions in highly challenging circumstances (Bullough, Renko, and Myatt 2014) and with coping with failures (Cope 2011) and everyday adversities (Davydov et al. 2010). Indeed, while there is growing interest in understanding the factors and mechanisms affecting individual creativity (Liu, Jiang, Shalley, Keem, and Zhou 2016) and resilience (Benight and Cieslak 2011; Britt, Shen, Sinclair, Grossman, and Klieger 2016), previous research has overlooked them and their antecedents among university graduate entrepreneurs.

A second tension faced by entrepreneurs is related to their career autonomy and responsibility (Arthur, Claman, and DeFillippi 1995), which stimulates individual creativity while requiring resilience to master increased autonomy and cope with emerging challenges and stressful uncertainties. Although prior organisational research has shown that individual and contextual factors affect individual creativity (Amabile 1988; Shalley and Gilson 2004; Shalley, Zhou, and Oldham 2004) and resilience (Bullough et al. 2013; Sinclair and Wallston 2004), for entrepreneurs the contexts vary. It follows that individual attributes might have a stronger impact on knowledge-intensive entrepreneurship and on individuals' capacity to begin a venture despite expected uncertainties and challenges as well. For instance, in their study on university graduates Guerrero et al. (2018) found that individuals' experiences, skills, and abilities more likely predict start-up creation than university support does.

It is likely that different sets of individual determinants contribute to entrepreneurship. As entrepreneurship research shows, entrepreneurs are driven by multiple motivations (Dubini 1989; Jayawarna, Rouse, and Kitching 2011). Amabile (1997) suggested that a motivational synergy of intrinsic and extrinsic motivations contributes to entrepreneurial creativity. Likewise, Nisula et al. (2017) found that a distinct set of entrepreneurial motivations drives entrepreneurs' and employees' creativity. Liu et al. (2016) stressed the need for research on the combined effects of various motivational 
and non-motivational mechanisms of individual creativity, as creativity in different contexts may require different mechanisms. Similarly, resilience scholars suggested that in addition to self-efficacy (Benight and Cieslak 2011), understanding the impact of factors other than motivational ones on individual resilience is essential. What is more, they also highlighted the need for studies on resilience among various types of workers, such as entrepreneurs (Bullough et al. 2014) and precariously employed workers (Britt et al. 2016). Apart from the antecedents of creativity and resilience differing between organisational employees and entrepreneurs, there might also be differences between entrepreneurs, but these aspects remain unclear.

Overall, the above debate and the limited research on university graduate entrepreneurship confirm the clear need to extend our understanding of the individual mechanisms that affect and enable high levels of creativity and resilience among such entrepreneurs; earlier studies on university graduate entrepreneurs have concentrated mainly on demographic characteristics and contextual aspects (Pickernell et al. 2011; Åsterbro et al. 2012; Greene and Saridakis 2007). Thus, the focus of our research is on motivations and self-concepts as antecedents of university graduate entrepreneurs' and preentrepreneurs' creativity and resilience. We also investigated whether university graduate entrepreneurs and pre-entrepreneurs have different demands in terms of motivations and self-concepts for creativity and resilience, that is, whether different mechanisms are in play. This knowledge is important, as there is growing pressure to understand the developing forms of contemporary entrepreneurship and to build corresponding entrepreneurship theories.

The theoretical underpinnings of this study are derived from the literature on individual creativity (Amabile et al. 1996), resilience (Sinclair and Wallston 2004), selfdetermination theory (SDT; Deci and Ryan 1985), social cognitive theory (SCT; Bandura 1997), and entrepreneurship (Jayawarna et al. 2011). We propose a theoretical model in which entrepreneurial motivations (achievement and materialism) and positive selfconcepts (general self-efficacy and internal locus of control) are linked to university graduate entrepreneurs' creativity and resilience. We test the proposed model using data from 282 Finnish university graduates and individual members of the TEK trade union, divided into two samples: 105 entrepreneurs with experience running a business and 177 pre-entrepreneurs who intend to start a business. We investigate whether the relationships between variables are contingent on the sample, as some recent studies suggest (Liu et al. 2016; Zhou and Hoever 2014).

The following section presents the development of the conceptual framework and research hypotheses. We then describe our research methods and findings and conclude with a discussion of the key findings, theoretical and practical contributions, and suggestions for future research. 


\section{Individual Determinants of Entrepreneurs' Creativity and Resilience}

\section{Defining University Graduate Entrepreneurs}

In this study, we focus on university graduate entrepreneurs, which we define in line with Pickernell et al.'s (2011) definition as entrepreneurs and pre-entrepreneurs who hold a doctorate, master's degree, or bachelor's degree. First, we define university graduate entrepreneurs as graduates who own a firm or earn their income at their own risk either full-time or part-time (freelance or through project-based contracts). Second, we describe university graduate pre-entrepreneurs based on Holley and Watson's (2017) definition as individuals who have graduated and intend to set up a firm and become entrepreneurs, although they currently earn wages or a salary either within academia or in an organisation. These two categories are based on earlier research entrepreneurship, in which intention is seen as a strong indicator (Fishbein and Ajzen 1975; Lee et al. 2011) and an initial step towards entrepreneurship (Holley and Watson 2017; Bullough and Renko 2013; Mosey and Wright 2007). As such, this categorisation is convergent with the broad focus of earlier research that encompasses not only being an entrepreneur but also being at the preentrepreneurial stage (Holley and Watson 2017), labelled as aspiring (Bullough and Renko 2013) and nascent entrepreneurs (Mosey and Wright 2007; Ucbasaran et al. 2003).

\section{Entrepreneurs' Creativity and Resilience}

Creativity, defined as the ability to generate novel and useful ideas (Amabile 1988), involves imagination, initiative, and perseverance to implement knowledge and insights into action in order to meet individual, group, and/or organisational goals (Oldham and Cummings 1996). As existing models of individual creativity rely on employee creativity within organisational settings, developing a model to understand the determinants of individual entrepreneurs' creativity, which Amabile (1997) labelled as entrepreneurial creativity, is needed. This is because the domain of entrepreneurs differs from the organisational domain, especially because entrepreneurs are autonomous actors who are responsible for their own decisions, income, and career. In this regard, we adopt earlier research on individual creativity and apply it to entrepreneurs because they are individual actors despite their context (Bullough and Renko 2013). While intrinsic motivation (Amabile 1988; Tierney and Farmer 2002) is also likely important for entrepreneurs' creativity, this creativity may demand multiple mechanisms (Liu et al. 2016), that is, the impact of intrinsic and extrinsic motivations and self-concepts. Thus, in entrepreneurship, various motivational and personal aspects or the situational combinations of these constitute the personal capacities through which entrepreneurs can demonstrate creativity 
throughout their entrepreneurial activity. We believe that highly creative entrepreneurs are successful because they have a strong personal capacity to use their knowledge in multiple ways in order to engage in entrepreneurial activities.

Resilience, "a dynamic process encompassing positive adaptation within the context of significant adversity" (Luthar et al. 2000, 543), refers to an individual's process of facing and overcoming experiences of adversity (Sinclair and Wallston 2004; Tedeschi and Calhoun 2004). Some scholars understand resilience to include everyday adversities, as well as significant stressors or losses (Davydov et al. 2010), both of which are more than likely in entrepreneurship. Thus, an entrepreneur's ability to cope with adversity and emerging setbacks is an implicit necessity. Scholars have examined resilience among employees in challenging or stressful jobs, such as teaching (Tait 2008; Brunetti 2006), military operations (Britt, Adler, and Bartone 2001), and industrial work (Britt, Shen, Sinclair, and Grossman 2016). Bullough and Renko (2013) and Bullough et al. (2014) found a positive link between resilience and entrepreneurial intentions in challenging circumstances. Hence, resilient entrepreneurs are prepared to address emerging problems directly and are likely to establish new businesses despite failures. Resilience may also be associated with the courage to start and run one's own business (see Miller and Le BretonMiller 2017). Although entrepreneur's resilience is attracting increased attention among scholars (Fisher et al. 2016; Roche et al. 2014), there is scant research investigating the personal factors related to university graduate entrepreneurs' resilience. We expect that for university graduates, entrepreneurship may appear as a stressful and demanding process entailing significant changes that call for resilience and creativity, and university graduate entrepreneurs with high levels of resilience may appear successful because they have a strong personal capacity to cope with the various adversities that emerge in entrepreneurship.

\section{Theoretical Background}

Deci and Ryan's (1985) SDT suggests that both intrinsic and extrinsic motivations explain individual behaviour and performance. Although intrinsic motivation is associated with creativity (Amabile 1997; Tierney and Farmer 2002), the impact of both intrinsic and extrinsic motivations (Amabile 1997) is less studied. To address this research void, we use entrepreneurial motivations (Jayawarna et al. 2011) because evidence suggests that the entrepreneurial motivations of achievement (intrinsic) and materialism (extrinsic) positively relate to entrepreneurial behaviour (Jayawarna et al. 2011) and freelancers' successful careers (Born and Witteloostuijn 2013), both of which involve creativity (Dul et al. 2011; Chen and Yang 2009; Zhou 2008). Furthermore, Amabile (1993) suggested that in complex work, a synergy of intrinsic and extrinsic motivations may lead to the high levels of novelty and appropriateness of solutions necessary for entrepreneurship. While 
SDT is used to investigate creativity, no extensive research connecting individual motivations with university graduate entrepreneurs' resilience exists.

Furthermore, we use the positive self-concepts of general self-efficacy and internal locus of control (Judge, Locke, and Durham 1997) because earlier research has shown that both motivations and self-concepts explain individual creativity (Liu et al. 2016) and resilience (Britt et al. 2016). This is consistent with Bandura's (1986) SCT, which states that through self-efficacy beliefs, individuals are able to master their goals. In addition, people with a strong internal locus of control have a greater sense of autonomy, control over their environment (Spector 1982), and preference for conditions of self-control (Rotter 1966), which reflect entrepreneurial circumstances. Benight and Cieslak (2011) associated self-efficacy and internal locus of control with resilience. In knowledge-intensive entrepreneurship in which individuals autonomously set their goals, self-efficacy and internal locus of control (Judge and Bono 2001) are especially important for creativity and resilience. On this basis, we propose that entrepreneurial achievement motivation and materialism motivation, along with the self-concepts of self-efficacy and internal locus of control, are strongly and positively linked to university graduate entrepreneurs' creativity and resilience. Figure 1 below displays our research model, and in the following chapter, we present the theoretical basis and advance our hypotheses. 


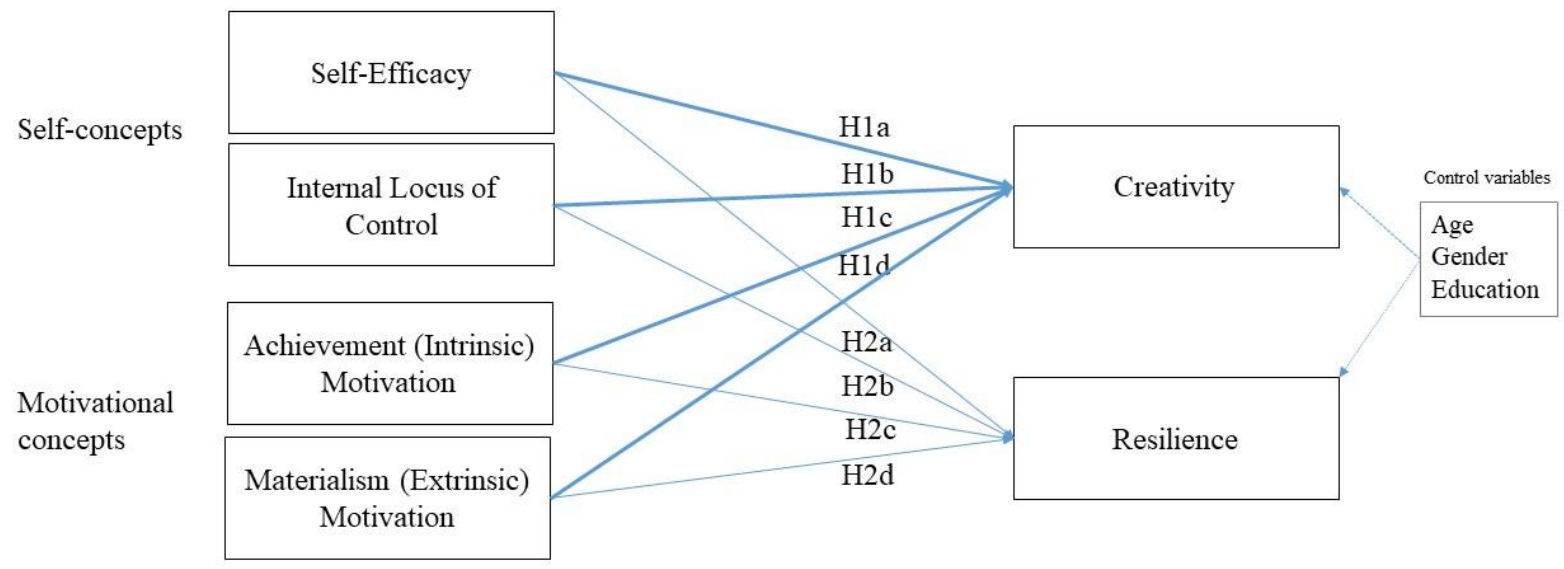

Figure 1: Research Model

\section{Positive Self-Concepts as Determinants of University Graduate Entrepreneurs' Creativity and Resilience}

Self-efficacy, as described in SCT (Bandura 1997), is a "generative capability in which cognitive, social, emotional and behavioural subskills must be organised and effectively orchestrated to serve innumerable purposes" (Bandura 1997, 37). It is central to effective entrepreneurial functioning because individuals with a high level of self-efficacy may strengthen and use their skills and abilities to navigate a variety of ambiguous circumstances (Bandura 1993).

Domain-specific creative self-efficacy is most often associated with individual creativity (Tierney and Farmer 2002). By contrast, general self-efficacy (Chen, Gully, and Eden 2001), which refers to one's confidence in performing successfully across demands in a wide variety of situations (Bandura 1993), is associated with entrepreneurial behaviour (Markman, Balkin, and Baron 2002). For instance, Markman et al. (2002) found that entrepreneurs have higher general self-efficacy than non-entrepreneurs. General selfefficacy reflects the confidence demands of entrepreneurship, so a high level of general 
self-efficacy can be associated with creativity, that is, an entrepreneur's courage to explore and step out of his or her comfort zone. Consequently, university graduate entrepreneurs' confidence in their ability to experiment beyond familiar practices and knowledge inherently reflects entrepreneurship. We therefore posit the following hypothesis:

H1a: General self-efficacy positively relates to creativity among university graduate entrepreneurs.

SCT can explain the link between general self-efficacy and resilience among entrepreneurs such that while resilience refers to one's ability to survive and thrive in challenging situations, self-efficacy refers to the strength of effort in such situations (Bandura 1997). Those who believe strongly in their capabilities exert greater effort when facing obstacles or failures in entrepreneurship, and they quickly recover after setbacks, whereas those with lower levels of self-efficacy may curtail their efforts and give up relatively quickly (Bandura 1997; Chen et al. 2001). Swarzer and Warner (2013) stated that self-efficacy may promote resilience by enabling the activation of motivational and behavioural mechanisms in stressful situations, which are likely to emerge for individuals starting and running businesses. Scholars (Sinclair and Wallston 2004; Tschannen-Moran and Hoy 2001) reported a positive link between self-efficacy and resilience, implying that self-efficacious people also possess strong coping strategies (Leana and Feldman 1994). Indeed, self-efficacy is an important personal coping resource (Leana and Feldman 1994) that reflects one's ability to manage stress and conflicts; thus, it likely promotes entrepreneurs' resilience (Bullough and Renko 2013). The stronger entrepreneurs' confidence in mastering a variety of difficult situations, the more resilience they are likely to build, the better they are at recovering and the stronger they become as entrepreneurs (Bullough et al. 2014). Accordingly, we posit the following hypothesis:

H2a. General self-efficacy positively relates to resilience among university graduate entrepreneurs.

An internal locus of control refers to individuals' belief that they control a broad array of factors in their environment and life (Judge and Bono 2001; Boone, Brabander, and Witteloostuijn 1996), which is inherently characteristic of entrepreneurs. Individuals with an internal locus of control consider themselves active actors and believe that they control their behavioural outcomes and are in control in most situations (Chen et al. 1998; Rotter 1966). Miller and Toulouse (1986) found that leaders' internal locus of control contributes positively to firm performance and that it is particularly important in dynamic environments. Sexton and Bowman (1985) reported that entrepreneurs have a stronger internal locus of control compared with managers. 
Chadha (1989) established a significant relationship between an internal locus of control and creativity. Likewise, Pannels and Claxton (2008) suggested that individuals with an internal locus of control may be more likely to find happiness through creativity. Aware of the paucity of previous research, we advance the following explorative hypothesis to investigate positive self-concepts related to university graduate entrepreneurs' creativity:

H1b: Internal locus of control positively relates to creativity among university graduate entrepreneurs.

In addition to creativity, one's internal locus of control has an impact on resilience. Previous research has shown that an internal locus of control (Rotter 1966) predicts entrepreneurial behaviours (Hansemark 2003; Venkatapathy 1984). In particular, evidence suggests a link between a strong internal locus of control and a high level of resilience (Luthar 1991; Werner 1995). Likewise, past research has indicated that individuals with a strong internal locus of control feel less pressure in their roles (Spector 1982), which is associated with coping abilities. We suggest that university graduate entrepreneurs with a strong internal locus of control believe they have more control over their lives and are therefore more likely to recover from hardships and setbacks and demonstrate resilience. Therefore, we propose the following hypothesis:

$\boldsymbol{H} 2 \boldsymbol{b}$ : Internal locus of control positively relates to resilience among university graduate entrepreneurs.

\section{Entrepreneurial Motivations as Determinants of University Graduate Entrepreneurs' Creativity and Resilience}

Achievement motivation, which is the desire for personal accomplishment and continuous development and the goal to attain results for autonomous reasons (Jayawarna et al. 2011), is an intrinsic factor. This is consistent with Deci and Ryan's (1985) SDT, in which intrinsic interest is demonstrated through personal achievement, the work itself, responsibility, and personal growth and development (Deci and Ryan 1985; Hertzberg 1974). There is strong evidence that intrinsic motivation is key to individual creativity (Amabile 1988; Shalley et al. 2004; Tierney and Farmer 2002). In general, university graduates are intrinsically motivated, as developing a high level of education and expertise requires significant investments of time, effort, desire, and motivation (Amabile 1993). Achievement-oriented individuals are curious, prefer novel solutions, and seek challenging opportunities (James and Mazerolle 2002). They tend to be imaginative, take the initiative, and possess a greater entrepreneurial spirit (Hansemark 2003; Venkatapathy 1984), and their perception of risk affects their belief that they can succeed in business operations (Gist 
and Mitchell 1992). Therefore, university graduate entrepreneurs with a high level of achievement motivation interpret the risks of creative solutions in a positive light and as stimulating challenges (Shalley 1995), and they can manage their problem-solving abilities, which are likely to lead to even higher levels of creativity. We therefore hypothesise the following:

H1c: Achievement motivation positively relates to creativity among university graduate entrepreneurs.

Achievement motivation is also related to entrepreneurs' resilience, as intrinsically motivated and achievement-oriented entrepreneurs are willing to exert more effort when facing problems or failures. Past research has associated achievement motivation with entrepreneurial behaviour (Hansemark 2003). The enjoyment of work for its own sake drives achievement-motivated individuals. Achievement motivation is associated with resilience in the sense that intrinsically motivated individuals are not only aware of potentially emerging problems and are able to take them as sources of novel ideas and learning, but they are also prepared to master related difficulties, setbacks, and emotional disappointments. Research shows that a high level of intrinsic motivation, among other personal resources, contributes to teachers' resilience ( $\mathrm{Gu}$ and Day 2007; Kitching, Morgan, and O'Leary 2009). Individuals who are hardworking, ambitious, confident and resourceful, that is, individuals who demonstrate achievement motivation characteristics, also show resilience (Britt et al. 2016). Therefore, we propose that achievement motivation contributes to university graduate entrepreneurs' resilience:

H2c: Achievement motivation positively relates to resilience among university graduate entrepreneurs.

Materialism is typically classified as an extrinsic motivation; it is the tendency to be driven by outside stimuli, such as material incentives or tangible outcomes (Dubini 1989), rewards (Amabile et al. 1996), financial success, or a good job (Carter et al. 2003; Ryan and Deci 2000). Studies on entrepreneurship (Jayawarna et al. 2011), freelance career success (Born and Witteloostuijn 2013), and expert creativity (Nisula et al. 2017) indicate that entrepreneurs' motivational capital comprises both intrinsic and extrinsic motivations, and successful entrepreneurial functioning demands both achievement and materialism motivation.

Research on the impact of extrinsic motivations on creative expert performance has yielded mixed results (An et al. 2016). Extrinsic motivation has been found not only to reduce intrinsic interest and creativity (Eisenberger and Aselage 2009) but also to improve creative performance (An et al. 2016; Eisenberger and Aselage 2009; Deci and Ryan 1985). 
While research has yielded mixed results regarding the impact of extrinsic motivation on academics' entrepreneurial activities (Perkmann et al. 2013; Lam 2011), the link between extrinsic motivation and creativity is less studied. However, in entrepreneurship, materialism motivation likely contributes differently to entrepreneurs' creativity because entrepreneurship demands creativity ranging from the generation of novel products and business opportunities to seeking income and firm turnover; that is, entrepreneurs need to constantly create novel solutions and capture novel opportunities in order to succeed in business. We therefore hypothesise the following:

H1d: Materialism motivation positively relates to creativity among university graduate entrepreneurs.

To build a link between materialism motivation and university graduate entrepreneurs' resilience, we draw from earlier entrepreneurship literature. As stated above, different motivations explain entrepreneurial behaviour, and materialistic motivation is central to entrepreneurship (Jayawarna et al. 2011; Born and Witteloostuijn 2013) and the creativity of academic experts (Nisula et al. 2017). Hence, entrepreneurs are motivated not only intrinsically but also by materialism. As resilience is associated with entrepreneurs' capacity to master a variety of adversities (Bullough and Renko 2013; Bullough et al. 2014), we theorise that entrepreneurs seeking higher incomes or firm turnover are driven by materialism motivation, and the stronger the motivation, the more likely an entrepreneur is to possess a high level of resilience. This is consistent with the suggestion of Benight and Cieslak (2011) for more studies on the relationship between motivation and resilience in order to extend the understanding of human resilience. We therefore posit the following explorative hypothesis:

H2d: Materialism motivation positively relates to resilience among university graduate entrepreneurs.

\section{Methodology}

\section{Data Collection}

We obtained data from Finnish university graduate entrepreneurs who are members of a trade union promoting the benefit of this interest group - Academic Engineers and Architects in Finland (TEK) - via a web-based questionnaire administered in March to May 2016. We distributed 4,940 questionnaires and received 423 responses, resulting in a response rate of 8.6 percent. This is typical of external web-based surveys involving TEK members. In addition to entrepreneurs, we also included pre-entrepreneurs because earlier research has shown that intention is a strong indicator of behaviour (Fishbein and Ajzen 1975; Lee et al. 2011) and is an initial step towards entrepreneurship 
(Bullough and Renko 2013; Holley and Watson 2017; Mosey and Wright 2007). We categorised entrepreneurs by identifying respondents who had current or previous activities either as full-time or part-time entrepreneurs. We categorised pre-entrepreneurs by determining respondents who are university graduates with the intention of starting a business or becoming entrepreneurs (Holley and Watson 2017) through the survey question "Have you seriously considered becoming an entrepreneur?" (Yes/No responses). The final sample comprised 282 respondents of which 37.2 percent $(N=105)$ were entrepreneurs and 62.8 percent $(N=177)$ were pre-entrepreneurs considering entrepreneurship (Table 1$)$. The entrepreneurs $(N=105)$ represented small companies; 79.0 percent of the entrepreneurs earned less than $€ 80,000$, and 21.0 percent earned $€ 80,000$ or more.

To assess non-response bias, we identified later respondents as non-respondents (Armstrong and Overton 1977). The cut-off point for selecting later respondents was the modification of the survey (the elimination of two survey questions) during the final stages to increase the response rate. The results for the independent samples t-test show no differences between early $(N=215)$ and late $(N=63)$ respondents in any of the constructs.

Table 1: Demographic Distribution of the Respondents

\begin{tabular}{llcccc} 
& & \multicolumn{2}{c}{ Sample 1 } & \multicolumn{2}{c}{ Sample 2 } \\
Age (years) & \multicolumn{2}{c}{ Entrepreneurs(N=105) } & \multicolumn{2}{c}{ Pre-entrepreneurs (N=177) } \\
& & $\mathbf{N}$ & $\mathbf{\%}$ & $\mathbf{N}$ & \% \\
\hline & 29 or less & 7 & 6.7 & 20 & 11.3 \\
& $30-39$ & 14 & 13.3 & 35 & 19.8 \\
& $40-49$ & 27 & 25.7 & 54 & 30.5 \\
& $50-59$ & 26 & 24.8 & 40 & 22.6 \\
& 60 or more & 31 & 29.5 & 28 & 15.8 \\
& Total & $\mathbf{1 0 5}$ & $\mathbf{1 0 0 . 0}$ & $\mathbf{1 7 7}$ & $\mathbf{1 0 0 . 0}$ \\
\hline Gender & Female & 23 & 21.90 & 40 & 22.6 \\
& Male & 82 & 78.10 & 137 & 77.4 \\
\hline Education & Student & - & - & 8 & 4.5
\end{tabular}




$\begin{array}{lrrrr}\begin{array}{l}\text { Other } \\ \begin{array}{l}\text { Bachelor's } \\ \text { degree }\end{array}\end{array} & 2 & 1.9 & - & - \\ \begin{array}{l}\text { Master's } \\ \text { degree }\end{array} & 81 & 1,0 & 6 & 3.4 \\ \begin{array}{l}\text { Doctoral } \\ \text { degree }\end{array} & 21 & 77.1 & 136 & 76.8 \\ \text { Total } & \mathbf{1 0 5} & 20.0 & 27 & 15.3 \\ & & \mathbf{1 0 0 . 0} & \mathbf{1 7 7} & \mathbf{1 0 0 . 0}\end{array}$

NOTE: Entrepreneurs are university graduate respondents who have current or previous activity either as full-time or part-time entrepreneurs. Pre-entrepreneurs are university graduate respondents with the intention of starting a business or becoming entrepreneurs (Holley and Watson 2017).

\section{Measures}

We used multi-item measures for the constructs with a seven-point Likert scale (1 $=$ strongly disagree, $7=$ strongly agree) for each construct based on existing measures in the literature (see Appendix I). We measured individual creativity using a six-item scale adapted from Tierney, Farmer, and Graen's (1999) study. We used the self-report method, as the respondents themselves are in the best position to evaluate their creative behaviour (Shalley et al. 2009; Conway and Lance 2010). For resilience, we used the validated and reliable Brief Resilient Coping Scale of Sinclair and Wallston (2004). To measure internal locus of control, we used a five-item scale by Chen et al. (1998). We measured general self-efficacy using Chen et al.'s (2001) scale, which demonstrates reliability and validity. Regarding the motivational constructs, we measured achievement motivation and materialism motivation using Jayawarna et al.'s (2011) three-item scales. Finally, we controlled for gender $(0=$ female, $1=$ male $)$ and education to partial out their influence on resilience and creativity. We classified the respondents' ages into five categories $(1=29$ years or younger, $2=30-39,3=40-49,4=50-59$, and $5=60$ years or older) and their education level into five categories, as well $(1=$ student, $2=$ other, $3=$ bachelor's degree, $4=$ master's degree, and $5=$ doctoral degree) .

\section{Data Analysis}

We used partial least squares (PLS; version 3.2.7 of SmartPLS; see Ringle et al. 2015) and IBM SPSS Statistics 24 software for the analyses. To assess the model's predictive accuracy $\left(\mathrm{R}^{2}\right)$ and the significance of structural paths, we applied the PLS bootstrapping procedure. Table 2 shows all statistical analyses. 
The construct reliability (CR) and convergent validity of all constructs demonstrated high internal consistency. All constructs in the two samples (see Table 2) have a CR value above the 0.7 threshold determined by Bagozzi and Yi (1988). Furthermore, all the average variance extracted (AVE) values exceeded the 0.5 cut-off determined by Fornell and Larcker (1981). Discriminant validity indicates the extent to which any one construct differs from the others. As shown in Table 2, the square root of each construct's AVE value was greater than the variance shared between the constructs in the model (Fornell and Larcker 1981). Additionally, all the outer loadings of each item exceeded the 0.60 cut-off (Barclay et al. 1995; Fornell and Larcker 1981). Therefore, the measures demonstrate sufficient validity and reliability in operationalising the study variables.

Table 2 displays a correlation matrix of the two samples. Significant correlations were observed between the independent variables and dependent variables, suggesting a complex link between the constructs.

Table 2: Correlation Matrix, Internal Consistency, and Discriminant Validity Statistics for All Measures

\begin{tabular}{|c|c|c|c|c|c|c|c|c|c|c|}
\hline SAMPLE $1(\mathrm{~N}=105)$ & Mean & SD & AVE & CR & 1. & 2. & 3. & 4. & 5. & 6. \\
\hline 1. Achievement & 5.591 & 0.8400 & 0.537 & 0.771 & 0.733 & & & & & \\
\hline 2. Creativity & 5.376 & 0.8375 & 0.563 & 0.885 & $0.406^{* * *}$ & 0.750 & & & & \\
\hline 3. Internal locus of control & 5.192 & 0.7770 & 0.442 & 0.798 & 0.202 & $0.255^{*}$ & 0.665 & & & \\
\hline 4. Materialism & 5.391 & 0.8339 & 0.467 & 0.713 & $0.370^{*}$ & $0.401 * *$ & $0.295^{* *}$ & 0.683 & & \\
\hline 5. Resilience & 5.131 & 0.8826 & 0.491 & 0.794 & $0.522^{* * *}$ & $0.379 * *$ & $0.455^{* *}$ & $0.278^{*}$ & 0.701 & \\
\hline 6. Self-efficacy & 5.948 & 0.6599 & 0.582 & 0.893 & $0.284 * *$ & $0.549 *$ & $0.574 * *$ & $0.370^{* *}$ & $0.405^{* *}$ & 0.763 \\
\hline SAMPLE 2 (N=177) & Mean & SD & AVE & $\mathrm{CR}$ & 1. & 2. & 3. & 4. & 5. & 6. \\
\hline 1. Achievement & 5.060 & 0.8683 & 0.508 & 0.755 & 0.713 & & & & & \\
\hline 2. Creativity & 4.984 & 0.9404 & 0.591 & 0.896 & $0.531 * *$ & 0.769 & & & & \\
\hline
\end{tabular}




\begin{tabular}{|c|c|c|c|c|c|c|c|c|c|}
\hline 3. Internal locus of control & 5.092 & 0.8571 & 0.504 & 0.835 & $0.407 * *$ & $0.329^{* * *}$ & 0.710 & & \\
\hline 4. Materialism & 5.362 & 0.9069 & 0.544 & 0.779 & $0.347 * *$ & $0.310^{* * *}$ & $0.359 * *$ & 0.738 & \\
\hline 5. Resilience & 4.975 & 0.9918 & 0.548 & 0.827 & $0.571 * *$ & 0.519 ** & $0.434 * *$ & $0.351^{* *}$ & 0.740 \\
\hline 6. Self-efficacy & 5.853 & 0.7617 & 0.662 & 0.921 & $0.428 * *$ & $0.497 * *$ & $0.471 * *$ & $0.356^{* *}$ & $0.543^{* * *}$ \\
\hline
\end{tabular}

NOTE: ** Correlation is significant at the 0.01 level; * Correlation is significant at the 0.05 level ( 2 tailed).

\section{Assessment of Bias}

The research design and focus on the individual-level determinants of entrepreneurs support the use of self-reported measures (see Convey and Lance 2010). Hence, the respondents completed items addressing both independent and dependent variables, which are the likely sources of common method bias (CMB). However, the access policy of the TEK demanded an anonymous survey, so combining the respondents of two distinct surveys was not possible. Nevertheless, we used the following procedures to reduce the likelihood of CMB.

The survey and the items in the scales were improved with the help of practitioners in the field, resulting in clear and proper grammar and a compact survey (MacKenzie and Podsakoff 2012). As the respondents assessing concrete constructs were highly educated and experienced in the topic, the possibility of CMB is minor (MacKenzie and Podsakoff 2012). Furthermore, their confidentiality was assured explicitly via the anonymous survey, both in its design and administration (Podsakoff et al. 2003). The respondents thus less likely altered their answers as a result of perceptions of others' expectations, reducing the risk of CMB.

\section{Results}

\section{University Graduate Entrepreneurs' Creativity and Resilience}

The model was able to explain 45.1 percent of the variance in entrepreneurs' creativity and 41.8 percent of the variance in entrepreneurs' resilience.

We found that self-efficacy (H1a: $\beta=0.422 ; p<0.01$ ), achievement motivation (H1c: $\beta=0.247 ; p<0.01$ ), and materialism motivation (H1c: $\beta=0.178 ; p<0.05$ ) had a significant, positive effect on entrepreneurs' creativity (Table 3 ). Thus, the results support 
H1a, H1c, and H1d. This means that entrepreneurs who are confident in performing successfully across demands in a wide variety of situations, desire to achieve their personal goals, and are willing to make efforts in order to increase their income are likely to use their imagination and creativity for their entrepreneurial activities. Of the control variables, gender $(\beta=0.206 ; p<0.01)$ and education $(\beta=0.157 ; p<0.05)$ were significantly and positively related to creativity. It follows that the higher the level of education, the higher the entrepreneur's creativity. In addition, male entrepreneurs were more creative than their female counterparts.

As shown in Table 3, internal locus of control (H2b: $\beta=0.325 ; p<0.01)$ and achievement motivation (H2c: $\beta=0.390 ; p<0.01$ ) had a positive and significant impact on entrepreneurs' resilience, which supports $\mathrm{H} 2 \mathrm{~b}$ and $\mathrm{H} 2 \mathrm{c}$. Hence, entrepreneurs who desire to achieve their personal goals and believe that they can control a broad array of factors in their environment and life are likely to overcome the experiences of adversity and emergent setbacks that entrepreneurship involves.

\section{University Graduate Pre-entrepreneurs' Creativity and Resilience}

The model was able to explain 41.8 percent of the variance in pre-entrepreneurs' creativity and 51.2 percent of the variance in pre-entrepreneurs' resilience.

As shown in Table 3, self-efficacy (H1a: $\beta=0.300 ; p<0.01$ ) and achievement motivation (H1c: $\beta=0.355 ; p<0.01$ ) had a positive and significant impact on preentrepreneurs' creativity, supporting H1a and H1c. Hence, pre-entrepreneurs who are confident in performing successfully across demands in a wide variety of situations and who desire to achieve their personal goals are likely use their imagination and creativity to explore and step out of their comfort zone in order to capture opportunities and create novel business ideas and products. Of the control variables, education $(\beta=0.108 ; p<0.10)$ was significantly and positively related to pre-entrepreneurs' creativity, indicating that the higher the pre-entrepreneur's education level, the higher his or her creativity.

Table 3: Results of the Hypothesised Model for University Graduate Entrepreneurs and Pre-entrepreneurs

\begin{tabular}{lcccc} 
& $\begin{array}{l}\text { Sample 1 } \\
\text { Entrepreneurs (N=105) }\end{array}$ & \multicolumn{2}{l}{$\begin{array}{l}\text { Sample 2 } \\
\text { Pre-entrepreneurs (N=177) }\end{array}$} \\
\hline Hypotheses/Path & $\boldsymbol{\beta}$ & T-Value & $\boldsymbol{\beta}$ & T-Value \\
\hline
\end{tabular}




\begin{tabular}{|c|c|c|c|c|}
\hline H1a: Self-efficacy $\rightarrow$ Creativity & 0.422 & $3.962 * * *$ & 0.300 & $3.324 * * *$ \\
\hline H1b: Locus of control $\rightarrow$ Creativity & -0.134 & 1.085 & 0.037 & 0.456 \\
\hline H1c: Achievement $\rightarrow$ Creativity & 0.247 & $2.921 * * *$ & 0.355 & $4.625^{* * *}$ \\
\hline H1d: Materialism $\rightarrow$ Creativity & 0.178 & $2.192 * *$ & 0.092 & 1.301 \\
\hline Age $\rightarrow$ Creativity & -0.037 & 0.413 & 0.080 & 1.213 \\
\hline Education $\rightarrow$ Creativity & 0.157 & $2.303 * *$ & 0.108 & $1.895^{*}$ \\
\hline \multirow[t]{2}{*}{ Gender $\rightarrow$ Creativity } & 0.206 & $2.619 * * *$ & 0.053 & 0.911 \\
\hline & \multicolumn{2}{|c|}{$\mathbf{R}^{2}=\mathbf{0 . 4 5 1}$} & \multicolumn{2}{|c|}{$\mathbf{R}^{2}=\mathbf{0 . 4 1 7}$} \\
\hline Hypotheses/Path & $\beta$ & T-Value & $\beta$ & T-Value \\
\hline H2a: Self-efficacy $\rightarrow$ Resilience & 0.133 & 1.353 & 0.310 & $4.332 * * *$ \\
\hline H2b: Locus of control $\rightarrow$ Resilience & 0.325 & $2.998 * * *$ & 0.098 & 1.437 \\
\hline H2c: Achievement $\rightarrow$ Resilience & 0.390 & $3.626 * * *$ & 0.400 & $6.341 * * *$ \\
\hline H2d: Materialism $\rightarrow$ Resilience & 0.006 & 0.048 & 0.091 & 1.376 \\
\hline Age $\rightarrow$ Resilience & 0.124 & 1.567 & 0.039 & 0.693 \\
\hline Education $\rightarrow$ Resilience & -0.016 & 0.212 & -0.139 & $2.722 * * *$ \\
\hline \multirow[t]{2}{*}{ Gender $\rightarrow$ Resilience } & -0.059 & 0.559 & -0.109 & $1.742 *$ \\
\hline & \multicolumn{2}{|c|}{$\mathrm{R}^{2}=\mathbf{0 . 4 1 8}$} & \multicolumn{2}{|c|}{$\mathbf{R}^{2}=\mathbf{0 . 5 1 2}$} \\
\hline
\end{tabular}

Note: $* * *$ Significance $<0.01 ; * *$ Significance $<0.05 ; *$ Significance $<0.10$.

With regard to $\mathrm{H} 2$, self-efficacy $(\mathrm{H} 2 \mathrm{a}: \beta=0.310 ; p<0.01)$ and achievement motivation (H2c: $\beta=0.400 ; p<0.01$ ) had a positive and significant impact on preentrepreneurs' resilience, supporting $\mathrm{H} 2 \mathrm{a}$ and $\mathrm{H} 2 \mathrm{c}$. Hence, pre-entrepreneurs who are confident in performing successfully across demands in a wide variety of situations and who desire to achieve their personal goals are likely to face and overcome the experiences of adversity and emergent setbacks that entrepreneurship involves. Of the control variables, education $(\beta=-0.139 ; 0.01)$ and gender $(\beta=-0.109 ; 0.10)$ were significantly and negatively related to resilience. This finding means that bachelor-level pre-entrepreneurs are likely to be the most resilient, whereas doctoral-level pre-entrepreneurs are less resilient. In addition, female pre-entrepreneurs are distinctly more resilient than their male counterparts.

Table in Appendix II summarises our results. Overall, we found that university graduate entrepreneurs and pre-entrepreneurs were differentiated by the set of determinants that contributed to their creativity and resilience. On the one hand, general self-efficacy, achievement motivation, and materialism motivation contribute to entrepreneurs' creativity, whereas general self-efficacy and achievement motivation contributed to preentrepreneurs' creativity. On the other hand, internal locus of control and achievement 
motivation contributed to entrepreneurs' resilience, whereas general self-efficacy and achievement motivation contributed to pre-entrepreneurs' resilience (see Appendix II).

\section{Discussion and Conclusion}

The purpose of this study is to extend our understanding of the individual-level determinants of creativity and resilience among university graduate entrepreneurs who are either entrepreneurs or pre-entrepreneurs. On the basis of the results obtained using data from members of the trade union TEK in Finland, we found that different sets of motivations and self-concepts explain creativity and resilience among university graduate entrepreneurs and pre-entrepreneurs. Particularly, a broader set of individual determinants (motivations and self-concepts) contribute to entrepreneurs' creativity and resilience compared with pre-entrepreneurs' creativity. Consequently, our study provides implications for three ongoing theoretical discussions as follows.

\section{Theoretical Implications}

First, our study adds to the limited research on the factors affecting individual entrepreneurs' creativity and resilience (Markman et al. 2002; Bullough and Renko 2013) among university graduate entrepreneurs, in particular, by providing a theoretical model that considers both creativity and resilience as important individual capacities for an entrepreneur to master the tensions of entrepreneurship. While earlier research has identified and studied entrepreneurs' creativity (Amabile 1997) and resilience (Bullough et al. 2014; Bullough and Renko 2013), these capacities have not been theorised together as central to entrepreneurs' starting and running a venture. In the present study, we examined the effects of both motivations and self-concepts on university graduate entrepreneurs' creativity and resilience. We built on prior insights that are the antecedents of individual creativity and resilience, such as Bandura's (1993) SCT, the concept of internal locus of control, and intrinsic and extrinsic motivations (Deci and Ryan 1985) in the organisational context, and we complement these previous models with insights from the entrepreneurship literature (Jayawarna et al. 2011). Furthermore, our study extends extant research on university graduate entrepreneurship by theorising and demonstrating that entrepreneurs differ in the individual determinants contributing to their creativity and resilience. Whereas self-efficacy and achievement motivation explain both the creativity and resilience of pre-entrepreneurs, entrepreneurs are distinct from pre-entrepreneurs in that the antecedents of their creativity and resilience are different and more varied than those of pre-entrepreneurs. Specifically, entrepreneurs' creativity is explained by selfefficacy, achievement motivation, and materialism motivation, and their resilience is explained by an internal locus of control and achievement motivation. 
In building on the theory of entrepreneurial motivations (Jayawarna et al. 2011) and by showing that both achievement and materialism motivation contribute to university graduate entrepreneurs' creativity, our study complements earlier research on entrepreneurship that has found that intrinsic and extrinsic motivations drive academic experts' creativity (Nisula et al. 2017), entrepreneurial creativity (Amabile 1997), and entrepreneurship (Jayawarna et al. 2011). Furthermore, we extend research on university graduate entrepreneurs by revealing that positive self-concepts are important for their creativity and resilience. Specifically, we show that general self-efficacy (Chen et al. 2001) contributes both to university graduate entrepreneurs' and pre-entrepreneurs' creativity, whereas earlier research has associated general self-efficacy with entrepreneurship (Markman et al. 2002), finding that entrepreneurs have higher general self-efficacy than non-entrepreneurs. While earlier research has found that internal locus of control predicts entrepreneurial behaviours (Hansemark 2003; Venkatapathy 1984), we show that it also contributes to the resilience of entrepreneurs but not to the resilience of pre-entrepreneurs among university graduates.

Second, with regard to the literature on individual creativity, our findings converge with and complement those of earlier research, which has shown a strong link between domain-specific creative self-efficacy (Tierney and Farmer 2002), intrinsic motivation (Amabile 1988; Tierney and Farmer 2002), and individual creativity among employees.

Our findings complement earlier research by showing that general self-efficacy and entrepreneurial achievement motivation contribute to individual creativity among university graduate entrepreneurs. This finding is also consistent with SCT (Bandura 1986, 1977). Self-efficacy seems to be especially important for university graduate entrepreneurs, who are responsible for their own skill development and seek work opportunities to use their skills. Therefore, entrepreneurs need to master the use of their personal resources in an efficient and creative manner, which also reflects Bandura's (1993) view of selfefficacy.

What is more, our study extends research on individual creativity, showing that in addition to intrinsic motivation, materialistic motivation is also important for entrepreneurs' creativity. While research on entrepreneurial creativity acknowledges motivational synergy (Amabile 1997), it is far less studied among university graduate entrepreneurs. Furthermore, our finding that a higher education level increases the likelihood of a higher degree of creativity among both university graduate entrepreneurs and pre-entrepreneurs converges with research on individual creativity, which has identified human capital and domain-specific knowledge (associated with the level of education) as important to individual creativity (Amabile 1988) and entrepreneurship (Dickson, Solmon, and Weaver 2008). Regarding the role of gender in university graduate entrepreneurs' creativity, we found that male entrepreneurs are likely to be more creative 
than female entrepreneurs. This result might be attributed to the greater number of male respondents in our sample (78.1 percent). Finally, our study addresses the research call to investigate mechanisms affecting individual creativity (Liu et al. 2016) by exploring the impact of both motivations and positive self-concepts on university graduate entrepreneurs' creativity. In this regard, we diverge from previous literature on individual creativity, which has often addressed this type of creativity within organisational settings. Likewise, while previous research has examined these constructs separately (Liu et al. 2016), we considered both self-factors and entrepreneurial motivations simultaneously.

Third, in relation to the literature on entrepreneurs' resilience, earlier research on individual resilience (Britt et al. 2016, Gu and Day 2007; Kitching et al. 2009) has revealed a positive relationship between intrinsic motivation and individual resilience. Our findings converge with those of research by demonstrating that entrepreneurial achievement motivation positively relates to both entrepreneurs' and pre-entrepreneurs' resilience among university graduates.

Our finding that university graduate entrepreneurs and pre-entrepreneurs are distinct in terms of the determinants of their resilience is interesting. Whereas achievement motivation and an internal locus of control explain entrepreneurs' resilience, achievement motivation and general self-efficacy explain pre-entrepreneurs' resilience. This may be attributable to the differing contexts of university graduate entrepreneurs and preentrepreneurs, which may require different sets of motivations and self-concept factors. This finding converges with those of previous studies that show how an internal locus of control significantly contributes to entrepreneurial behaviour (Hansemark 2003; Miller and Toulouse 1986) and those that demonstrate a strong positive relationship between an internal locus of control and individual resilience (Luthar 1991; Werner 1995). Our study adds to this body of research by offering novel findings and showing that when university graduate entrepreneurs are intrinsically motivated and feel that they are able to control their environment and lives, their resilience is affected (Bullough et al. 2014). This is particularly important for entrepreneurs who are responsible for their own career and income.

Furthermore, we surprisingly found that the impact of education level on preentrepreneurs' creativity is positive, whereas its impact on pre-entrepreneurs' resilience is negative. This indicates that the higher pre-entrepreneurs' level of education, the higher their creativity and the lower their resilience. On the other hand, the lower their level of education, the lower their creativity and the higher their resilience. One explanation for this finding might be that pre-entrepreneurs employed by organisations demonstrate creativity in their own work in familiar work environments, which do not typically pose any remarkable adversity in stimulating their resilience. As resilience develops through experiences, that is, by engaging in activities that demand individuals to boost their resilience (Bullough and Renko 2013), university graduate pre-entrepreneurs who are 
employed by organisations may not face situations that enable them to cross boundaries; thus, they lack opportunities to exercise their resilience. In addition, pre-entrepreneurs may lack entrepreneurial education and training, as well as role models, in entrepreneurial activities (Miller et al. 2018). Regarding the role of gender in pre-entrepreneurs' resilience, we found that female pre-entrepreneurs are more resilient than their male counterparts. There exists no clear explanation for this finding, although it might have something to do with women still needing to "prove themselves" in organisational contexts especially in a predominantly male branch such as the examined one.

\section{Practical Implications}

Our study provides some important implications for those aiming to develop university graduate entrepreneurs' creativity and resilience.

We investigated general self-efficacy, internal locus of control, achievement motivation, and materialism motivation, which are malleable individual attributes compared with personality factors, which are more stable. These malleable aspects can be learnt (Hansemark 2003) and developed through training and experience (Dyal 1984; Bandura 1993; Bullough and Renko 2013). Thus, our findings suggest that by paying attention and developing these individual motivations and self-concepts that are critical for entrepreneurs' creativity and resilience, university graduate entrepreneurs can take responsibility for their personal development and performance. This implication involves university graduate entrepreneurs' self-management capacity, which has become increasingly important in today's business environment.

In addition, educators and other stakeholders, such as entrepreneur associations and trade unions for university graduate professionals aiming to promote their members' development and success, can streamline educational and training activities towards developing both motivational orientations and self-confidence to develop entrepreneurial capacities such as creativity and resilience. This is highly significant in the present business landscape because contemporary working life offers multiple and parallel opportunities for university graduates to utilise their knowledge, expertise, and creativity in a variety of contexts and circumstances which simultaneously demand confidence, capacity, and the courage to capture such emerging opportunities. Based on our findings it seems that, confident and highly motivated university graduate entrepreneurs are likely to be more creative and resilient than university graduate entrepreneurs with lower levels of confidence and motivation; hence, they are also more likely to succeed as entrepreneurs. 


\section{Limitations and Future Research}

This study has certain limitations. We tested the direct effect of independent variables on both creativity and resilience, ignoring the mediation or moderation effects between variables. While such relationships are likely, we considered these as issues for another study because testing for them also demands the development of a theoretical basis for the mediation or moderation hypotheses and are therefore a separate debate. The novelty of our research model and the set of self-concepts and entrepreneurial motivations justify our decision to test the direct relationships of these with creativity and resilience first. Consequently, we propose that future studies address the mediation and/or moderation effects in detail. Future studies could also investigate creativity and resilience as mediators or moderators between personal determinants and actualised entrepreneurship and the decision to embark on a venture. In addition, future studies could investigate the synergy of intrinsic and extrinsic motivations along the entrepreneurial process.

In our study, we considered university graduate entrepreneurs and preentrepreneurs with the intention of beginning entrepreneurial activity. Nonetheless, future studies need to consider a wider variety of contexts and fields of business when examining entrepreneurs' creativity and resilience. Overall, in future studies, scholars should shed light on the individual determinants and capacities of university graduate entrepreneurs, that is, entrepreneurs, pre-entrepreneurs, intrapreneurs (entrepreneurial university graduates), and academic entrepreneurs because individual capacities are becoming increasingly important, particularly for those who intend to be self-employed or to start a venture. In particular, universities, trade unions for university graduates, and other stakeholders aiming to foster entrepreneurship among university graduates would benefit from knowledge of the factors that differentiate entrepreneurs in the contemporary economy. Comparative studies between entrepreneurs in various stages of entrepreneurship (early stage or pre-entrepreneurs, novice entrepreneurs, and experienced entrepreneurs) and environments (small business, freelancers, academia and organisations [intrapreneurs]) would serve this need.

Our failure to identify entrepreneurs in a more fine-grained manner is another limitation of this study. This is due to the anonymity policy of TEK, which prevented us from asking about workplace and employer information, work position, and exact experiences. Therefore, we were not able to identify, for instance, academic entrepreneurs as a certain type of entrepreneur. To address this issue, future studies could investigate university graduate entrepreneurs in greater detail.

Our study investigated individual factors and excluded contextual ones. Previous research has considered individual variables as mediators between contextual factors and creative performance (Liu et al. 2016). Although entrepreneurs' contextual enablers, such 
as supervisors' support, work climate, and encouragement, differ from organisational employees' contextual enablers, we excluded them because the primary interest of our study was the individual antecedents of entrepreneurs' creativity and resilience. Consequently, future studies could consider both individual and contextual enablers of university graduate entrepreneurs' creativity and resilience.

Regarding the importance of contextual factors for university graduate entrepreneurship, there might be institutional, cultural, and regional aspects that motivate and drive (either push or pull) entrepreneurship among university graduates. In some contexts, such as that in this study (Finland), university graduates still perceive entrepreneurship as an unpopular choice (GEM Global Entrepreneurship Monitor, 2015) or a decision taken because of challenging situations (e.g. economic regression and the subsequent decrease in employment). Some other countries, such as Sweden and the Netherlands, have similar conditions in terms of university graduate entrepreneur activity (GEM Global Entrepreneurship Monitor 2015). By contrast, some highly entrepreneurial environments (such as Silicon Valley, London, or Shanghai) and universities with global influence may be more effective at motivating university graduates to engage in entrepreneurship, making it an attractive choice for university graduates. However, it is neither individual nor contextual factors alone that affect entrepreneurship among university graduates; rather, it is the situational interaction between these factors. Indeed, entrepreneurship grows in the interactions between individuals and environments, and individuals' attitudes towards entrepreneurship (Liñan and Chen 2009) develop through role models, education, and training under circumstances of an entrepreneurial and supporting environment. It is therefore likely that the attitudes towards entrepreneurship among younger generations are becoming more positive, which means that entrepreneurship among graduates is likely to grow in the near future. Consequently, future studies could examine the contextual factors affecting university graduates' capacities, such as creativity and resilience.

Finally, as our data were obtained from a limited field of university graduates in one country, Finland, the results may not be generalisable to other fields of university graduates or to countries with significantly different cultural and behavioural contexts. However, it is likely that these findings would apply to Western countries with a comparable level of technological development and with market economies where individual characteristics and performance are considered valuable for individual success; the findings would especially apply to those countries whose number of university graduate entrepreneurs is comparable to that of Finland (Nordic and European countries [GEM Global Entrepreneurship Monitor 2015] and whose university graduates are likely to face a somewhat similar context and external factors in terms of entrepreneurship. Nevertheless, 
we recommend that future research be conducted in different cultural and national contexts and among university graduates from a variety of fields.

\section{Conclusions}

Our study makes significant contributions to entrepreneurship research, particularly to entrepreneurship among university graduates. While contributing to the literature on entrepreneurs' creativity and resilience through the examination of both motivations and self-concepts, our research also provides guidance for educators and policy makers who aim to increase various forms of entrepreneurship. We believe that this kind of behavioural research in an authentic entrepreneurial context extends our understanding of the individual factors that affect entrepreneurs' capacities of creativity and resilience. Specifically, we identified two major tensions in which the generative dance between creativity and reliance is required. We suggest that these capacities may also explain why some university graduates choose or are able to choose entrepreneurship despite its challenges and adversities. By recognising the importance of entrepreneurial motivations and selfconcepts for entrepreneurs, educators and policy makers can use this information to better streamline education and assist university graduates who are hesitant to start their own business (thus missing out on opportunities). University graduates who are both intrinsically and extrinsically motivated and believe in their abilities and their control over events and their environment seem to be both creative and resilient. We hope that they serve as valuable examples to other university graduates and inspire and motivate them to start businesses and thus help foster societal growth and wellbeing.

\section{Funding}

This work was supported by the TEKES Finnish Funding Agency for Technology and Innovation [Dnro 2923/31/2014 Mom. 32.20.40.3/14].

\section{References}

Amabile, T. M. (1988). A model of creativity and innovation in organizations. Research in Organizational Behavior, 10(1),123-167. http://web.mit.edu/curhan/www/docs/Articles/15341_Readings/Group_Performance/Amabile_A_Model_of_Cre ativityOrg.Beh_v10_pp123-167.pdf

Amabile, T. M. (1993). Motivational synergy: Toward new conceptualizations of intrinsic and extrinsic motivation in the workplace. Human Resource Management Review, 3(3), 185-201. https://doi.org/10.1016/10534822(93)90012-S

Amabile, T. M. (1997). Entrepreneurial creativity through motivational synergy. The Journal of Creative Behavior, 31(1), 18-26. https://doi.org/10.1002/j.2162-6057.1997.tb00778.x 
Amabile, T. M., Conti, R., Coon, H., Lazenby, J., \& Herron, M. (1996). Assessing the work environment for creativity. Academy of Management Journal, 39(5), 1154-1184. https://doi.org/10.5465/256995

An, D., Song, Y., \& Carr, M. (2016). A comparison of two models of creativity: Divergent thinking and creative expert performance. Personality and Individual Differences, 90, 78-84. https://doi.org/10.1016/j.paid.2015.10.040

Armstrong, J. S., \& Overton, T. S. (1977). Estimating nonresponse bias inmail surveys. Journal of Marketing Research, 14(3), 396-402. https://doi.org/10.1177/002224377701400320

Arthur, M. B., Claman, P. H., \& DeFillippi, R. J. (1995). Intelligent enterprise, intelligent careers. The Academy of Management Executive, 9(4), 7-20. https://doi.org/10.5465/ame. 1995.9512032185

Åstebro, T., Bazzazian, N., \& Braguinsky, S. (2012). Startups by recent university graduates and their faculty: Implications for university entrepreneurship policy. Research Policy, 41(4), 663-677. https://doi.org/10.1016/j.respol.2012.01.004

Bagozzi, R. P., \& Yi, Y. (1988). On the evaluation of structural equation models. Journal of the Academy of Marketing Science, 16(1), 74-94. https://doi.org/10.1007/BF02723327

Bandura, A. (1977). Self-efficacy: Toward a unifying theory of behavioral change. Psychological Review, 84(2), 191. https://doi.org/10.1037/0033-295X.84.2.191

Bandura, A. (1986). Social foundations of thought and action: A social cognitive theory.Prentice Hall.

Bandura, A. (1993). Perceived self-efficacy in cognitive development and functioning. Educational Psychologist, 28(2), 117-148. https://doi.org/10.1207/s15326985ep2802_3

Bandura, A. (1997). Self-efficacy: The exercise of control. Macmillan.

Benight, C. C.,\&Cieślak, R. (2011). Cognitive factors and resilience: How self-efficacy contributes to coping with adversities. In B. Litz, D. Charney, \& M. J. Friedman (Eds.), Resilience and mental health. Challenges across the lifespan (pp. 45-55). Cambridge University Press.

Bennett, R., \& Robson, P. (2003). Changing use of external business advice and government supports by SMEs in the 1990s. Regional Studies, 37(8), 795-811.

Biraglia, A., \& Kadile, V. (2017). The role of entrepreneurial passion and creativity in developing entrepreneurial intentions: Insights from American homebrewers. Journal of Small Business Management, 55(1), 170-188. https://doi.org/10.1111/jsbm.12242

Boone, C., De Brabander, B., \& Van Witteloostuijn, A. (1996). CEO locus of control and small firm performance: An integrative framework and empirical test. Journal of Management Studies, 33(5), 667-700. https://doi.org/10.1111/j.1467-6486.1996.tb00814.x

Born, A., \& Witteloostuijn, A. (2013). Drivers of freelance career success. Journal of Organizational Behavior, 34(1), 24-46. https://doi.org/10.1002/job.1786

Britt, T. W., Adler, A. B., \& Bartone, P. T. (2001). Deriving benefits from stressful events: The role of engagement in meaningful work and hardiness. Journal of Occupational Health Psychology, 6(1), 53. https://doi.org/10.1037/1076-8998.6.1.53

Britt, T. W., Shen, W., Sinclair, R. R., Grossman, M. R., \& Klieger, D. M. (2016). How much do we really know about employee resilience? Industrial and Organizational Psychology, 9(2), 378-404. https://doi.org/10.1017/iop.2015.107 
Brunetti, G. J. (2006). Resilience under fire: Perspectives on the work of experienced, Inner City High School Teachers in the United States. Teaching and Teacher Education, 22(7),812-825. https://doi.org/10.1016/j.tate.2006.04.027

Bullough, A., \& Renko, M. (2013). Entrepreneurial resilience during challenging times. Business Horizons, 56(3), 343-350. https://doi.org/10.1016/j.bushor.2013.01.001

Bullough, A., Renko, M., \& Myatt, T. (2014). Danger zone entrepreneurs: The importance of resilience and selfefficacy for entrepreneurial intentions. Entrepreneurship Theory and Practice, 38(3), 473-499. https://doi.org/10.1111/etap.12006

Carter, N. M., Gartner, W. B., Shaver, K. G., \& Gatewood, E. J. (2003). The career reasons of nascent entrepreneurs. Journal of Business Venturing, 18(1), 13-39. https://doi.org/10.1016/S0883-9026(02)00078-2

Chadha, N. K. (1989). Causal antecedents of self-concept, locus of control and academic achievement: A path analysis. Psychologia: International Journal of Psychology in the Orient, 32(4), $264-268$. https://psycnet.apa.org/record/1990-23872-001

Chen, C. C., Greene, P. G., \& Crick, A. (1998). Does entrepreneurial self-efficacy distinguish entrepreneurs from managers? Journal of Business Venturing, 13(4), 295-316. https://doi.org/10.1016/S0883-9026(97)00029-3

Chen, G., Gully, S. M., \& Eden, D. (2001). Validation of a new general self-efficacy scale. Organizational Research Methods, 4(1), 62-83. https://doi.org/10.1177/109442810141004

Chen,M. H., \& Yang, Y. J. (2009). Typology and performance of new ventures in Taiwan: A model based on opportunity recognition and entrepreneurial creativity. International Journal ofEntrepreneurial Behavior and Research, 15(5), 398-414. https://doi.org/10.1108/13552550910982997

Clarysse, B., Tartari, V., \& Salter, A. (2011). The impact of entrepreneurial capacity, experience and organizational support on academic entrepreneurship. Research Policy, 40(8), 1084-1093. https://doi.org/10.1016/j.respol.2011.05.010

Conway, J. M., \& Lance, C. E. (2010). What reviewers should expect from authors regarding common method bias in organizational research. Journal of Business and Psychology, 25(3), 325-334. https://doi.org/10.1007/s10869-010-9181-6

Cope, J. (2011). Entrepreneurial learning fromfailure:An interpretative phenomenological analysis. Journal of Business Venturing, 26(6), 604-623. https://doi.org/10.1016/j.jbusvent.2010.06.002

Davydov, D. M., Stewart, R., Ritchie, K., \& Chaudieu, I. (2010). Resilience and mental health. Clinical Psychology Review, 30(5), 479-495. https://doi.org710.1016/j.cpr.2010.03.003

Deci, E. L., \& Ryan, R. M. (1985). The general causality orientations scale: Self-determination in personality. Journal of Research in Personality, 19(2), 109-134. https://doi.org/10.1016/0092-6566(85)90023-6

Dickson, P. H., Solomon, G. T., \& Weaver, K. M. (2008). Entrepreneurial selection and success: Does education matter? Journal of Small Business and Enterprise Development, 15(2), $239-258$. https://doi.org/10.1108/14626000810871655

Dubini, P. (1989). The influence of motivations and environment on business start-ups: Some hints for public policies. Journal of Business Venturing, 4(1), 11-26. https://doi.org/10. 1016/0883-9026(89)90031-1

Dul, J., Ceylan, C., \& Jaspers, F. (2011). Knowledge workers' creativity and the role of the physical work environment. Human ResourceManagement, 50(6), 715-734. https://doi.org/10.1002/hrm.20454 
Eisenberger, R., \& Aselage, J. (2009). Incremental effects of reward on experienced performance pressure: Positive outcomes for intrinsic interest and creativity. Journal of Organizational Behavior, 30(1), 95-117. https://doi.org/10.1002/job.543

Fishbein, M., \& Ajzen, I. (1975). Belief, attitude, intention and behavior: An introduction to theory and research. Addison-Wesley.

Fisher, R., Maritz, A., \& Lobo, A. (2016). Does individual resilience influence entrepreneurial success. Academy of Entrepreneurship Journal, 22(2), 39-53.

Fornell, C., \& Larcker, D. F. (1981). Structural equation models with unobservable variables and measurement error: Algebra and statistics. Journal of Marketing Research, 18(3), 382-388. https://doi.org/10.1177/002224378101800313

“GEM Global entrepreneurship Monitor, Finnish 2015 Report” by University of Turku. ISBN-978-951-29-65663 9/2016. Retrieved September 15, 2019, from https://tem.fi/documents/1410877/2132284/GEM+2015/272cebde$\underline{1 b 2 c-4 f e f-949 e-f 3609 f 0 f b f a 3}$

Gist, M. E., \& Mitchell, T. R. (1992). Self-efficacy: A theoretical analysis of its determinants and malleability. Academy of Management Review, 17(2), 183-211. https://doi.org/10.5465/amr.1992.4279530

Grandi, A., \& Grimaldi, R. (2005). Academics' organizational characteristics and the generation of successful business ideas. Journal of Business Venturing, 20(6), 821-845. https://doi.org/10.1016/j.jbusvent.2004.07.002

Greene, F. J., \& Saridakis, G. (2007). Understanding the factors influencing graduate entrepreneurship. National Council for Graduate Entrepreneurship Research Report, $1, \quad 2007$. https://doi.org/10.1.1.868.5413\&rep=rep1\&type $=$ pdf

Gu, Q.,\&Day,C. (2007). Teachers' resilience: A necessary condition for effectiveness. Teaching and Teacher Education, 23(8), 1302-1316. https://doi.org/10.1016/j.tate.2006.06.006

Guerrero, M., Urbano, D., Cunningham, J. A., \& Gajón, E. (2018). Determinants of graduates’ start-ups creation across a Multi-Campus Entrepreneurial University: The case of Monterrey Institute of Technology and Higher Education. Journal of Small Business Management, 56(1), 150-178. https://doi.org/10.1111/jsbm.12366

Hansemark, O. C. (2003). Need for achievement, locus of control and the prediction of business start-ups: A longitudinal study. Journal of Economic Psychology, 24(3), 301-319. 950 https://doi.org/10.1016/S01674870(02)00188-5

Herzberg, F. (1974). Motivation-hygiene profiles. Pinpointing what ails the organization. Organizational Dynamics, 3(2), 18-29.

Hitt, M. A., Ireland, R. D., Camp, S. M., \& Sexton, D. L. (2002). Strategic entrepreneurship: Integrating entrepreneurial and strategic management perspectives. In M. A. Hitt,

R. D. Ireland, S. M. Camp, \& D. L. Sexton (Eds.), Strategic entrepreneurship: Creating a new mindset (pp. 1-16). Blackwell Publishing.

Holley, A. C., \& Watson, J. (2017). Academic entrepreneurial behavior: Birds of more than one feather. Technovation, 64-65, 50-57. https://doi.org/10.1016/j.technovation.2017.07.001

Hsu, D. H., Roberts, E. B., \& Eesley, C. E. (2007). Entrepreneurs from technology-based universities: Evidence from MIT. Research Policy, 36(5), 768-788. https://doi.org/10.1016/j.respol.2007.03.001

James, L. R., \& Mazerolle, M. D. (2002). Personality in work organizations. Sage. 
Jansen, S., van de Zande, T., Brinkkemper, S., Stam, E., \& Varma, V. (2015). How education, stimulation, and incubation encourage student entrepreneurship: Observations from MIT, IIIT, and Utrecht University. The International Journal of Management Education, 13(2),170-181. https://doi.org/10.1016/j.ijme.2015.03.001

Jayawarna, D., Rouse, J., \& Kitching, J. (2011). Entrepreneur motivations and life course. International Small Business Journal, 31(1), 34-56. https://doi.org/10.1177/0266242611401444

Judge, T. A., \& Bono, J. E. (2001). Relationship of core self-evaluations traits-self-esteem, generalized selfefficacy, locus of control, and emotional stability - with job satisfaction and job performance: A meta-analysis. Journal of Applied Psychology, 86(1), 80. https://doi.org/10.1037/0021-9010.86.1.80

Judge, T. A., Locke, E. A., \& Durham, C. C. (1997). The dispositional causes of job satisfaction: A core evaluations approach. Research in Organizational Behavior, 19, 151-188. https://www. scirp.org/(S(i43dyn45teexjx455qlt3d2q))/reference/ReferencesPapers.aspx?ReferenceID=1722943

Kitching, K., Morgan, M., \& O’Leary, M. (2009). It's the little things: exploring the importance of commonplace events for early-career teachers' motivation. Teachers and Teaching:Theory and Practice, 15(1), 43-58. https://doi.org/10.1080/13540600802661311980

Lam, A. (2011). What motivates academic scientists to engage in research commercialization:'Gold', 'ribbon'or 'puzzle'? Research Policy, 40(10), 1354-1368. https://doi.org/10.1016/j.respol.2011.09.002

Lazear, E. P. (2005). Entrepreneurship. Journal of Labor Economics, 23(4), 649-680. https://doi.org/10.1086/491605

Leana, C. R., \& Feldman, D. C. (1994). The psychology of job loss. Research in Personnel and Human Resources Management, 12(27), 1-302.

Lee, L., Wong, P. K., Der Foo, M., \& Leung, A. (2011). Entrepreneurial intentions: The influence of organizational and individual factors. Journal of Business Venturing, 26(1), 124-136. https://doi.org/10.1016/j.jbusvent.2009.04.003 990

Liñán, F., \& Chen, Y. W. (2009). Development and cross-cultural application of a specific instrument to measure entrepreneurial intentions. Entrepreneurship Theory and Practice, 33(3), 593-617. https://doi.org/10.1111/j.1540$\underline{6520.2009 .00318 . x}$

Liu, D., Jiang, K., Shalley, C. E., Keem, S., \& Zhou, J. (2016). Motivational mechanisms of employee creativity: A meta-analytic examination and theoretical extension of the creativity literature. Organizational Behavior and Human Decision Processes, 137(Nov.), 236-263. https://doi.org/10.1016/j.obhdp.2016.08.001

Luthar, S. S. (1991). Vulnerability and resilience: A study of high-risk adolescents. Child Development, 62(3), 600-616. https://doi.org/10.2307/1131134

Luthar, S. S., Cicchetti, D., \& Becker, B. (2000). The construct of resilience: A critical evaluation and guidelines for future development. Child Development, 71(3), 543-562. https://doi.org/10.1111/1467-8624.00164

MacKenzie, S. B., \& Podsakoff, P. M. (2012). Common method bias in marketing: Causes, mechanisms, and procedural remedies. Journal of Retailing, 88(4), 542-555. https://doi.org/10.1016/j.jretai.2012.08.001

Markman, G. D., Balkin, D. B., \& Baron, R. A. (2002). Inventors and new venture formation: The effects of general self-efficacy and regretful thinking. Entrepreneurship Theory and Practice, 27(2), 149-165. https://doi.org/10.1111/1540-8520.00004

Miller, D., \& Breton-Miller, L. (2017). Sources of entrepreneurial courage and imagination: Three perspectives, three contexts. Entrepreneurship Theory and Practice, 35(5), 855-872. https://doi.org/10.1111/etap.12281 
Miller, D., \& Toulouse, J. M. (1986). Chief executive personality and corporate strategy and structure in small firms. Management Science, 32(11), 1389-1409. https://doi.org/10.1287/mnsc.32.11.1389

Miller, K., McAdam, R., \& McAdam, M. (2018). A systematic literature review of university technology transfer from a quadruple helix perspective: Toward a research agenda. R\&D Management, 48(1), 7-24. https://doi.org/10.1111/radm.12228

Mosey, S., \& Wright, M. (2007). From human capital to social capital: A longitudinal study of technology-based academic entrepreneurs. Entrepreneurship Theory and Practice, 31(6), 909-935. https://doi.org/10.1111/j.1540$\underline{6520.2007 .00203 . x}$

Nisula, A.-M., Olander, H., \& Henttonen, K. (2017). Entrepreneurial motivations as drivers of expert creativity. International Journal of Innovation Management, 21(5), 1740005. https://doi.org/10.1142/S1363919617400059

Oldham, G. R., \& Cummings, A. (1996). Employee creativity: Personal and contextual factors at work. Academy of Management Journal, 39(3), 607-634. https://doi.org/10.5465/256657

Pannels, T. C., \& Claxton, A. F. (2008). Happiness, creative ideation, and locus of control. Creativity Research Journal, 20(1), 67-71. https://doi.org/10.1080/10400410701842029

Perkmann, M., Tartari, V., McKelvey, M., Autio, E., Broström, A., D’Este, P., \& Krabel, S. (2013).Academic engagement and commercialisation: A review of the literature on University-Industry relations. Research Policy, 42(2), 423-442. https://doi.org/10.1016/j.respol.2012.09.007

Pickernell, D., Packham, G., Jones, P., Miller, C., \& Thomas, B. (2011). Graduate entrepreneurs are different: They access more resources? International Journal of Entrepreneurial Behavior \& Research, 17(2), 183-202. https://doi.org/10.1108/13552551111114932

Pittaway, L., \& Cope, J. (2007). Entrepreneurship education: A systematic review of the evidence. International Small Business Journal, 25(5), 479-510. https://doi.org/10.1177/0266242607080656

Podsakoff, P. M., MacKenzie, S. B., Lee, J. Y., \& Podsakoff, N. P. (2003). Common method biases in behavioral research: A critical review of the literature and recommended remedies. Journal of Applied Psychology, 88(5), 879. https://doi.org/10.1037/0021-9010.88.5.879

Ringle, C. M., Wende, S., \& Becker, J. (2015). SmartPLS 3. SmartPLS GmbH.

Roche, M., Haar, J. M., \& Luthans, F. (2014). The role of mindfulness and psychological capital on the well-being of leaders. Journal of Occupational Health Psychology, 19(4), 476. https://doi.org/10.1037/a0037183

Rotter, J. B. (1966). Generalized expectancies for internal versus external control of reinforcement. Psychological Monographs, 80(609). https://doi.org/10.1037/h0092976

Ryan, R. M., \& Deci, E. L. (2000). Intrinsic and extrinsic motivations: Classic definitions and new directions. Contemporary Educational Psychology, 25(1), 54-67. https://doi.org/10.1006/ceps.1999.1020

Schwarzer, R., \& Warner, L. M. (2013). Perceived self-efficacy and its relationship to resilience. In S. PrinceEmbury \& D. H. Saklofske (Eds.), The Springer series on human exceptionality: Resilience in children, adolescents, and adults: Translating research into practice (pp. 139-150). Springer Science + Business Media.

Sexton, D. L., \& Bowman, N. (1985). The entrepreneur: A capable executive and more. Journal of Business Venturing, 1(1), 129-140. https://doi.org/10.1016/0883-9026(85)90012-6

Shalley, C. E. (1995). Effects of coaction, expected evaluation, and goal setting on creativity and productivity. Academy of Management Journal, 38(2), 483-503. https://doi.org/10.5465/256689 
Shalley, C. E., \& Gilson, L. L. (2004). What leaders need to know: A review of social and contextual factors that can foster or hinder creativity. The Leadership Quarterly, 15(1), 33-53. https://doi.org/10.1016/j.leaqua.2003.12.004

Shalley, C. E., Gilson, L. L., \& Blum, T. C. (2009). Interactive effects of growth need strength, work context, and job complexity on self-reported creative performance. Academy of Management Journal, 52(3), 489-505. https://doi.org/10.5465/amj.2009.41330806

Shalley, C. E., Zhou, J., \& Oldham, G. R. (2004). The effects of personal and contextual characteristics on creativity: Where should we go from here? Journal of Management, 30(6), 933-958. https://doi.org/10.1016/j.jm.2004.06.007

Silverstone, Y., Tambe, H., \& Cantrell, S. M. (2015). The rise of the extended workforce. Accenture Strategy.

Sinclair, V. G.,\&Wallston, K.A. (2004). The development and psychometric evaluation of the brief resilient coping scale. Assessment, 11(1), 94-101. https://doi.org/10.1177/10731911032581441070

Spector, P. E. (1982). Behavior in organizations as a function of employees' locus of control. Psychological Bulletin, 91(3), 482. https://doi.org/10.1037/0033-2909.91.3.482

Tait, M. (2008). Resilience as a contributor to novice teacher success, commitment, and retention. Teacher Education Quarterly, 35(4), 57-75.

Tedeschi, R. G., \& Calhoun, L. G. (2004). Post-traumatic growth: Conceptual foundations and empirical evidence. Psychological Inquiry, 15(1), 1-18. https://doi.org/10.1207/s15327965pli1501_01

TEK Labour Market Survey. 2018. TEK. https://www.tek.fi/fi/uutishuone/tutkimukset/tyomarkkinatutkimus-tmt

Tierney, P., \& Farmer, S. M. (2002). Creative self-efficacy: Its potential antecedents and relationship to creative performance. Academy of Management Journal, 45(6), 1137-1148.https://doi.org/10.5465/3069429

Tierney, P., Farmer, S. M., \& Graen, G. B. (1999). An examination of leadership and employee creativity: The relevance of traits and relationships. Personnel Psychology, 52(3), 591-620. https://doi.org/10.1111/j.17446570.1999.tb00173.x

Tschannen-Moran, M., \& Hoy, A. W. (2001). Teacher efficacy: Capturing an elusive construct. Teaching and Teacher Education, 17(7), 783-805. https://doi.org/10.1016/S0742-051X(01)00036-1

Ucbasaran, D., Lockett, A., Wright, M., \& Westhead, P. (2003). Entrepreneurial founder teams: Factors associated with member entry and exit. Entrepreneurship Theory and Practice, 28(2), $107-128$. https://doi.org/10.1046/j.1540-6520.2003.004.x

Urbano, D., \& Guerrero, M. (2013). Entrepreneurial universities: Socioeconomic impacts of academic entrepreneurship in a European region. Economic Development Quarterly, 27(1),40-55. https://doi.org/10.1177/0891242412471973

Venkatapathy, R. (1984). Locus of control among entrepreneurs: A review. Psychological Studies, 29(1), 97-100.

Werner, E. E. (1995). Resilience in development. Current Directions in Psychological Science, 4(3), 81-84. https://doi.org/10.1111/1467-8721.ep10772327

Zhou, J. (2008). New look at creativity in the entrepreneurial process. Strategic Entrepreneurship Journal, 2(1), 15. https://doi.org/10.1002/sej.38 1100 
Zhou, J., \& Hoever, I. J. (2014). Research on workplace creativity: A review and redirection. Annual Review of Organizational Psychology and Organizational Behavior, 1(1), 333-359. https://doi.org/10.1146/annurevorgpsych-031413-091226

Åstebro, T., Bazzazian, N., and Braguinsky, S. (2012). 'Startups by recent university graduates and their faculty: Implications for university entrepreneurship policy’. Research policy, 41(4), 663-677. https://doi.org/10.1016/j.respol.2012.01.004

\section{Appendix I: Constructs, Items, and Loadings}

\begin{tabular}{|c|c|c|c|}
\hline Construct & Item wording & $\begin{array}{l}\text { Loadings } \\
\text { Sample } 2\end{array}$ & $\begin{array}{l}\text { Loadings } \\
\text { Sample } 1\end{array}$ \\
\hline \multirow{7}{*}{$\begin{array}{l}\text { Creativity (Tierney, } \\
\text { Farmer, and Graen } \\
\text { 1999) }\end{array}$} & $\begin{array}{l}\text { Please indicate to what extent the following statements characterize you } \\
(1=\text { never, } 4=\text { sometimes, } 7=\text { always })\end{array}$ & & \\
\hline & I take risks in terms of producing new ideas in doing my job. & 0.713 & 0.711 \\
\hline & I solve problems that had caused others difficulty. & 0.733 & 0.644 \\
\hline & I try out new ideas and approaches to problems. & 0.817 & 0.753 \\
\hline & I identify opportunities for new products/processes. & 0.771 & 0.800 \\
\hline & I generate novel and operable ideas. & 0.837 & 0.818 \\
\hline & I generate ideas revolutionary to my field. & 0.732 & 0.761 \\
\hline $\begin{array}{l}\text { Internal locus of } \\
\text { control (Chen et al. } \\
\text { 1998) }\end{array}$ & $\begin{array}{l}\text { Please respond to the following statements by indicating the extent to } w \\
(1=\text { completely disagree, } 7=\text { completely agree })\end{array}$ & agree or & with them. \\
\hline
\end{tabular}


I am usually able to protect my personal interests. $\quad 0.714 \quad 0.590$

My life is determined by my own actions. $\quad 0.734 \quad 0.726$

I can pretty much determine what will happen in my life. $\quad 0.673 \quad 0.717$

When I make plans, I am almost certain to make them work. $\quad 0.744 \quad 0.622$

When I get what I want, it's usually because I worked hard for it. $\quad 0.682 \quad 0.661$

$\begin{array}{ll}\text { Achievement } & \text { How important do you personally consider the following items in relation to work? } \\ \text { motivation } & (1=\text { not at all important, } 7=\text { extremely important })\end{array}$

(Jayawarna et al.

2011)

Continue learning

Have responsibility

$0.648 \quad 0.774$

Materialism How important do you personally consider the following items in relation to work?

motivation $\quad(1=$ not at all important, $7=$ extremely important $)$

(Jayawarna et al.

2011)

\begin{tabular}{|c|c|c|c|}
\hline & Make lots of money & 0.653 & 0.565 \\
\hline & Give myself and my family security & 0.677 & 0.542 \\
\hline & Realize my dreams & 0.866 & 0.888 \\
\hline \multirow[t]{5}{*}{$\begin{array}{l}\text { Resilience (Sinclair } \\
\text { and Wallston 2004) }\end{array}$} & $\begin{array}{l}\text { How well do the following statements describe your behaviour and actions? } \\
(1=\text { the statement does not describe you at all, } 7=\text { describes you very well })\end{array}$ & & \\
\hline & I actively look for ways to replace the losses I encounter in life. & 0.647 & 0.657 \\
\hline & I believe that I can grow in positive ways by dealing with difficult situations. & 0.818 & 0.703 \\
\hline & I look for creative ways to alter difficult situations & 0.816 & 0.742 \\
\hline & Regardless of what happens to me, I believe I can control my reaction to it. & 0.663 & 0.699 \\
\hline \multirow{8}{*}{$\begin{array}{l}\text { General self-efficacy } \\
\text { (Chen, Gully, and } \\
\text { Eden 2001) }\end{array}$} & How well do the following statements describe you? & & \\
\hline & ( 1 = the statement does not describe you at all, $7=$ describes you very well $)$ & & \\
\hline & When facing difficult tasks, I am certain that I will accomplish them. & 0.768 & 0.739 \\
\hline & In general, I think that I can achieve outcomes that are important to me. & 0.809 & 0.693 \\
\hline & I believe I can succeed in almost any endeavour to which I set my mind. & 0.781 & 0.788 \\
\hline & I will be able to successfully overcome many challenges. & 0.824 & 0.803 \\
\hline & I am confident that I can perform effectively in many different tasks. & 0.822 & 0.773 \\
\hline & Even when things are tough, I can perform quite well. & 0.873 & 0.778 \\
\hline
\end{tabular}

\section{Appendix II}

\begin{tabular}{|l|c|c|}
\hline Hypotheses & $\mathbf{1 .}$ & $\mathbf{2 .}$ \\
\hline $\begin{array}{l}\text { H1a: General self-efficacy positively relates to creativity among university graduate } \\
\text { entrepreneurs }\end{array}$ & $\mathbf{+}$ & $\mathbf{+}$ \\
\hline $\begin{array}{l}\text { H1b: } \text { Internal locus of control positively relates to creativity among university graduate } \\
\text { entrepreneurs }\end{array}$ & Ns. & Ns. \\
\hline $\begin{array}{l}\text { H1c: Achievement motivation positively relates to creativity among university graduate } \\
\text { entrepreneurs. }\end{array}$ & + & + \\
\hline $\begin{array}{l}\text { H1d: Materialism motivation positively relates to creativity among university graduate } \\
\text { entrepreneurs. }\end{array}$ & + & Ns. \\
\hline $\begin{array}{l}\text { H2a. General self-efficacy positively relates to resilience among university graduate } \\
\text { entrepreneurs. }\end{array}$ & Ns. & + \\
\hline
\end{tabular}




\begin{tabular}{|l|c|c|}
\hline $\begin{array}{l}\text { H2b: Internal locus of control positively relates to resilience among university graduate } \\
\text { entrepreneurs. }\end{array}$ & + & Ns. \\
\hline $\begin{array}{l}\text { H2c: Achievement motivation positively relates to resilience among university graduate } \\
\text { entrepreneurs }\end{array}$ & + & + \\
\hline $\begin{array}{l}\text { H2d: Materialism motivation positively relates to resilience among university graduate } \\
\text { entrepreneurs. }\end{array}$ & Ns. & Ns. \\
\hline
\end{tabular}

Notes: $1=$ University graduate entrepreneur;

$2=$ University graduate pre-entrepreneur

$+=$ Significant;

Ns. = non-significant 